\title{
Effect of Preplant Irrigation, Nitrogen Fertilizer Application Timing, and Phosphorus and Potassium Fertilization on Winter Wheat Grain Yield and Water Use Efficiency
}

\author{
Jacob T. Bushong, D. Brian Arnall, and William R. Raun \\ Department of Plant and Soil Sciences, Oklahoma State University, 368 Agricultural Hall, Stillwater, OK 74078, USA \\ Correspondence should be addressed to D. Brian Arnall; b.arnall@okstate.edu
}

Received 14 January 2014; Accepted 7 March 2014; Published 3 April 2014

Academic Editor: David Clay

Copyright (C) 2014 Jacob T. Bushong et al. This is an open access article distributed under the Creative Commons Attribution License, which permits unrestricted use, distribution, and reproduction in any medium, provided the original work is properly cited.

\begin{abstract}
Preplant irrigation can impact fertilizer management in winter wheat. The objective of this study was to evaluate the main and interactive effects of preplant irrigation, $\mathrm{N}$ fertilizer application timing, and different $\mathrm{N}, \mathrm{P}$, and $\mathrm{K}$ fertilizer treatments on grain yield and WUE. Several significant two-way interactions and main effects of all three factors evaluated were observed over four growing seasons for grain yield and WUE. These effects could be described by differences in rainfall and soil moisture content among years. Overall, grain yield and WUE were optimized, if irrigation or adequate soil moisture were available prior to planting. For rain-fed treatments, the timing of $\mathrm{N}$ fertilizer application was not as important and could be applied before planting or topdressed without much difference in yield. The application of $\mathrm{P}$ fertilizer proved to be beneficial on average years but was not needed in years where above average soil moisture was present. There was no added benefit to applying $\mathrm{K}$ fertilizer. In conclusion, $\mathrm{N}$ and $\mathrm{P}$ fertilizer management practices may need to be altered yearly based on changes in soil moisture from irrigation and/or rainfall.
\end{abstract}

\section{Introduction}

Winter wheat (Triticum aestivum L.) is cultivated on approximately three million hectares of the of the United States' Central Rolling Red Plains, present in parts of Kansas, Oklahoma, and Texas [1]. The vast majority of these wheat hectares are cultivated under rain-fed conditions without irrigation. There are small isolated areas where wheat is grown with the aid of irrigation; one area in particular is the Lugert-Altus Irrigation District in southwestern Oklahoma. The irrigation water in this district is delivered to producer fields via canals from the Lake Lugert-Altus reservoir and applied through furrow or flood irrigation techniques. Though most of the water is utilized to irrigate cotton (Gossypium hirsutum L.), some producers have taken advantage of the available reservoir water in summer months to soften heavy textured surface soils in order to cultivate and prepare ground prior to wheat planting. The yearly amount of wheat hectares receiving irrigation in the counties that include the district ranges from zero hectares in years where there is not sufficient water in the reservoir to about 4,000 hectares [2].
Studies have shown that wheat planted into moist soil typically has increased emergence, stand establishment, and root growth, which can all lead to potentially higher grain yields [3]. The improved root development beneficially increases the potential soil water and nutrient reservoirs of the growing crop [4]. Researchers have reported that early season root growth can be stimulated with fertilizer, mainly nitrogen $(\mathrm{N})$, which increases the potential for greater water extraction from the soil profile. Studies in wheat have reported that increases in $\mathrm{N}$ fertilizer rate, typically increase water use efficiency (WUE) in both irrigated systems [5-7] and rainfed systems [8-10].

As previously stated, early increased root growth from adequate soil moisture can be advantageous for soil nutrient acquisition. This would be beneficial for nutrients that are immobile in the soil, such as $\mathrm{P}$ and $\mathrm{K}$. Relationships between soil water dependent root growth and plant $\mathrm{P}$ uptake have been observed in cereal grains, mostly because of the effects of soil moisture on the movement of phosphorus via diffusion and root development [11, 12]. Researchers have observed that plants take up more native soil $\mathrm{P}$ in more moist soil 
TABLE 1: Fertilizer rates and average soil test $\mathrm{P}$ and $\mathrm{K}$ for treatments in this study. $\mathrm{N}$ fertilizer was applied as urea (46-0-0) either preplant or midseason depending upon subplot assignment. $\mathrm{P}$ and $\mathrm{K}$ fertilizer treatments were all applied preplant as triple super phosphate (0-20-0) and muriate of potash (0-0-50), respectively.

\begin{tabular}{|c|c|c|c|c|c|c|c|}
\hline \multirow{3}{*}{ Treatment } & \multirow{2}{*}{\multicolumn{3}{|c|}{ Fertilizer treatment }} & \multicolumn{4}{|c|}{ Soil test values $^{\mathrm{a}}$} \\
\hline & & & & \multicolumn{2}{|c|}{ Irrigated } & \multicolumn{2}{|c|}{ Rain-fed } \\
\hline & $\mathrm{kg} \mathrm{N} \mathrm{ha}^{-1}$ & $\mathrm{~kg} \mathrm{P} \mathrm{ha}^{-1}$ & $\mathrm{~kg} \mathrm{Kha}^{-1}$ & $\mathrm{mg} \mathrm{P} \mathrm{kg}^{-1}$ & $\mathrm{mg} \mathrm{K} \mathrm{kg}^{-1}$ & $\mathrm{mg} \mathrm{P} \mathrm{kg}^{-1}$ & $\mathrm{mg} \mathrm{K} \mathrm{kg}^{-1}$ \\
\hline 1 & 0 & 0 & 0 & 6 & 302 & 4 & 334 \\
\hline 2 & 45 & 0 & 0 & 6 & 319 & 6 & 350 \\
\hline 3 & 90 & 0 & 0 & 6 & 320 & 7 & 350 \\
\hline 4 & 45 & 20 & 0 & 21 & 322 & 19 & 337 \\
\hline 5 & 90 & 20 & 0 & 19 & 312 & 27 & 337 \\
\hline 6 & 45 & 20 & 37 & 19 & 328 & 19 & 368 \\
\hline 7 & 90 & 20 & 37 & 17 & 320 & 19 & 373 \\
\hline
\end{tabular}

${ }^{\text {a }}$ Soil test $P$ and $K$ values derived from Mehlich 3 solution extraction (Mehlich, 1984 [30]).

environments and that the uptake of fertilizer $\mathrm{P}$ is not as sensitive to changes to soil moisture content [12-14]. A similar relationship between the plant availability of $\mathrm{K}$ and soil water dependent root growth also exists. Adequate or increased soil moisture content typically leads to increased root growth as well as the diffusive flux of $\mathrm{K}$ to the root surface [1517]. Providing adequate soil moisture content has also been shown to increase the efficiency of $\mathrm{K}$ fertilizer applications $[17,18]$.

The interactive effects of irrigation and N, P, and K fertilization have been evaluated with $\mathrm{N}$ most commonly being evaluated with $\mathrm{P}$ or K or the three together. The response to $\mathrm{N}$ fertilization is typically almost always observed regardless of irrigation or soil moisture content, but a response to $\mathrm{P}$ and/or $\mathrm{K}$ fertilization along with $\mathrm{N}$ fertilization is dependent on the amount of soil moisture, the timing the moisture is received by the growing crop, and the soil type [19-21].

Because $\mathrm{N}$ is mobile in the soil and taken up by the plant via mass flow mechanisms, $\mathrm{N}$ is typically taken up in greatest quantities during periods of active growth [22]. Much research has been conducted comparing yields and $\mathrm{N}$ fertilizer recovery of application timings and amounts in winter wheat. Some research has reported little to no added benefit to grain yield from spring or split $\mathrm{N}$ fertilization applications [23], but others have reported that significant grain yield increases when fertilization is split or spring applied [24, 25]. One consensus that has been reached is that split or spring $\mathrm{N}$ fertilizer applications increases the recovery of fertilizer $\mathrm{N}$ in the grain [23, 24, 26, 27].

The objective of this paper was to evaluate the effect of preplant irrigation, $\mathrm{N}$ fertilizer application timing, and $\mathrm{P}$ and $\mathrm{K}$ fertilization on winter wheat grain yields and WUE on a long-term soil fertility experiment site. The results of this evaluation will be used to assist in making proper $\mathrm{N}, \mathrm{P}$, and $\mathrm{K}$ fertilizer recommendations for optimizing grain yield and WUE in in the Central Rolling Red Plains.

\section{Materials and Methods}

This experiment was conducted at the Oklahoma State University Southwest Research and Extension Center located near Altus, Oklahoma. The soil type for the study area is a Hollister (Fine, smectitic, thermic Typic Haplusterts) silty clay loam [28]. The Hollister soil series is mapped extensively on over 900,000 hectares in the Central Rolling Red Plains and is used mainly for crop production [29]. The data was collected from a long-term winter wheat N, P, and K fertilizer trial that was established in 1966.

Treatments for the study area were split into areas that received either a single preplant irrigation or were strictly rain-fed. The $\mathrm{N}$ fertilizer treatments were applied all at once prior to planting or midseason just prior to first hollow stem at a rate of $45 \mathrm{~kg} \mathrm{Nha}^{-1}$ or $90 \mathrm{~kg} \mathrm{Nha}^{-1}$ as urea (46-0-0). The $\mathrm{P}$ fertilizer treatments were applied all at once prior to planting at a rate of $20 \mathrm{~kg} \mathrm{Pha}^{-1}$ as triple super phosphate $(0$ 20-0). The $\mathrm{K}$ fertilizer treatments were also applied all at once prior to planting at a rate $37 \mathrm{~kg} \mathrm{Kha}^{-1}$ as muriate of potash (0-0-50). A detailed list, with an assigned fertilizer treatment number, of the combination N-P-K fertilizer treatments along with an unfertilized check are described in Table 1. Irrigation water was always applied in late July or the first part of August using flood irrigation techniques at a rate of $100 \mathrm{~mm}$. Fertilizer treatments that were applied prior to planting were broadcast applied 30 to 45 days after irrigation and 45 to 60 days prior to planting and incorporated using conventional tillage techniques. Plots were broadcast seeded at a rate of approximately $100 \mathrm{~kg} \mathrm{ha}^{-1}$. Planting took place around the first of October and grain harvest occurred around the first of June. Best agronomic practices were employed for pest management and control. Specific dates of agronomic activities for each site year analyzed are reported in Table 2.

Plots for the irrigated and rain-fed treatments were 5.7 by 18.3 meters and 8.5 by 30.5 meters, respectively. Individual plots were harvested with a self-propelled, small plot grain combine and grain yields were adjusted to 12.5 percent moisture. Water use efficiency (WUE) was calculated for each treatment as the grain yield per unit of area per amount of water added through irrigation and rainfall and reported as $\mathrm{kg} \mathrm{ha}^{-1} \mathrm{~mm}^{-1}$. Weather data, which includes daily precipitation, temperature, and the 0 to $40 \mathrm{~cm}$ fractional water index (FWI), was downloaded from the nearby Oklahoma Mesonet [31] climate monitoring station. The FWI is a normalized 
TABLE 2: Dates of agronomic activities for growing seasons utilized in this study.

\begin{tabular}{lccccc}
\hline Year & Irrigation $^{\text {a }}$ & Preplant application & Planting & Topdress application & Harvest \\
\hline 2003 & Aug. 10, 2002 & Sept. 10, 2002 & Oct. 1, 2002 & Mar. 7, 2003 & May 30, 2003 \\
2004 & Aug. 5, 2003 & Sept. 17, 2003 & Oct. 1, 2003 & Mar. 11, 2004 & May 28, 2004 \\
2008 & Aug. 8, 2007 & Aug. 29, 2007 & Oct. 2, 2007 & Feb. 28, 2008 & Jun. 3, 2008 \\
2011 & Jul. 27, 2010 & Sept. 13, 2010 & Oct. 1, 2010 & Mar. 15, 2011 & Jun. 1, 2011 \\
\hline
\end{tabular}

${ }^{\mathrm{a}}$ Irrigation applied by flood at a rate of $100 \mathrm{~mm}$.

TABLE 3: Analysis of variance for main effects and interaction effects of factors affecting grain yield (GY) and water use efficiency (WUE) utilized in this study by growing season.

\begin{tabular}{|c|c|c|c|c|c|c|c|c|}
\hline \multirow{3}{*}{ Source } & \multicolumn{8}{|c|}{ Year } \\
\hline & \multicolumn{2}{|c|}{2003} & \multicolumn{2}{|c|}{2004} & \multicolumn{2}{|c|}{2008} & \multicolumn{2}{|c|}{2011} \\
\hline & GY & WUE & GY & WUE & GY & WUE & GY & WUE \\
\hline Water & * & $* *$ & * & $* *$ & * & * & $* *$ & ns \\
\hline $\mathrm{N}$ timing & ns & ns & * & * & ns & ns & ns & ns \\
\hline $\mathrm{N}$ timing $\times$ water & * & * & ns & ns & * & * & * & ns \\
\hline Treatment & $* * *$ & $* * *$ & $* * *$ & $* * *$ & $* * *$ & $* * *$ & $* * *$ & $* * *$ \\
\hline Treatment $\times \mathrm{N}$ timing & $*$ & $*$ & ns & * & * & * & * & $*$ \\
\hline Treatment $\times$ water & $* * *$ & $* *$ & ns & ns & $*$ & ns & $* * *$ & $* *$ \\
\hline Treatment $\times \mathrm{N}$ timing $\times$ water & ns & ns & ns & ns & ns & ns & ns & ns \\
\hline
\end{tabular}

$*, * *$, and $* * *$ are significant at the $0.1,0.01$, and 0.001 level, respectively.

ns: not significant at the 0.1 level.

value which ranges from 0.00 for very dry soil to 1.00 for soil at field capacity [32]. A summary of the collected weather data is displayed in Figures 1 and 2.

Growing seasons to be analyzed for this trial were selected by years that contained accurate irrigation data and reliable weather data and years where the wheat crop was taken to grain harvest. Prior to the 2001-2002 growing season, all $\mathrm{N}$ fertilizer treatments were applied preplant. After the 2001-2002 growing season, the $\mathrm{N}$ fertilizer treatments were split where half the $\mathrm{N}$ fertilizer treatments were applied all preplant or all midseason. After all the selection criteria were applied, four site years (2002-2003, 2003-2004, 2007-2008, and 2010-2011) were chosen for analysis. From this point forward, the site years will be referred to by the year of their grain harvest.

Soil test $\mathrm{P}$ and soil test $\mathrm{K}$ values had been collected at random times throughout the duration of this trial and were derived from a Mehlich 3 solution extraction [30]. Typically, soil samples were collected at a depth from 0 to $15 \mathrm{~cm}$ prior to fertilization and planting in the late summer. An average soil test value from over the entirety of this trial for each treatment is provided in Table 1 .

The experimental design was a split-split plot design with three replications. The main plot was water (irrigated, rainfed). The subplot was $\mathrm{N}$ fertilizer application timing (preplant and midseason). The sub-subplot was the N, P, and/or K fertilizer rate treatment (Table 1). Analysis of variance was used to determine significant ( $\mathrm{alpha}=0.10$ ) main and interaction effects of treatments on grain yield and WUE. Nonorthogonal contrasts were utilized to determine differences in specific treatment groupings.

\section{Results}

3.1. Effect on Grain Yield. Analysis of variance showed that there is no significant three-way interaction between irrigation, $\mathrm{N}$ fertilizer application time, and fertilizer treatment for any of the four growing seasons (Table 3). However, all three two-way interactions were significant for the 2003, 2008, and 2011 growing seasons. In 2004, there were no significant interaction effects, but all three main effects were observed to be significant (Table 3 ).

For the two-way interaction of irrigation and $\mathrm{N}$ fertilizer application timing for 2003, 2008, and 2011, grain yields were typically higher for treatments that were irrigated prior to planting (Table 4). Grain yields increased from 134 to $456 \mathrm{~kg} \mathrm{ha}^{-1}$ for irrigated plots that received $\mathrm{N}$ fertilizer preplant compared to irrigated plots that received topdress $\mathrm{N}$ fertilizer in February or March. Minimal difference was observed between rain-fed treatments that received $\mathrm{N}$ preplant compared to those that received topdress N. Rain-fed treatments that received topdress $\mathrm{N}$ fertilizer applications in the spring had from 51 to $285 \mathrm{~kg} \mathrm{ha}^{-1}$ higher grain yields than rain-fed treatments that received $\mathrm{N}$ fertilizer prior to planting.

When comparing the interaction of $\mathrm{N}$ fertilizer application timing and fertilizer treatment, grain yields were typically higher in plots that received $90 \mathrm{~kg} \mathrm{Nha}^{-1}$ prior to planting and had P fertilizer added in both 2003 and 2008 (Table 5). Single degree-of-freedom contrasts revealed a few significant differences (Table 5). Treatments that received $45 \mathrm{~kg} \mathrm{Nha}^{-1}$ preplant were not significantly different from plots that received $45 \mathrm{~kg} \mathrm{Nha}^{-1}$ topdress for 2008 and 2011; 

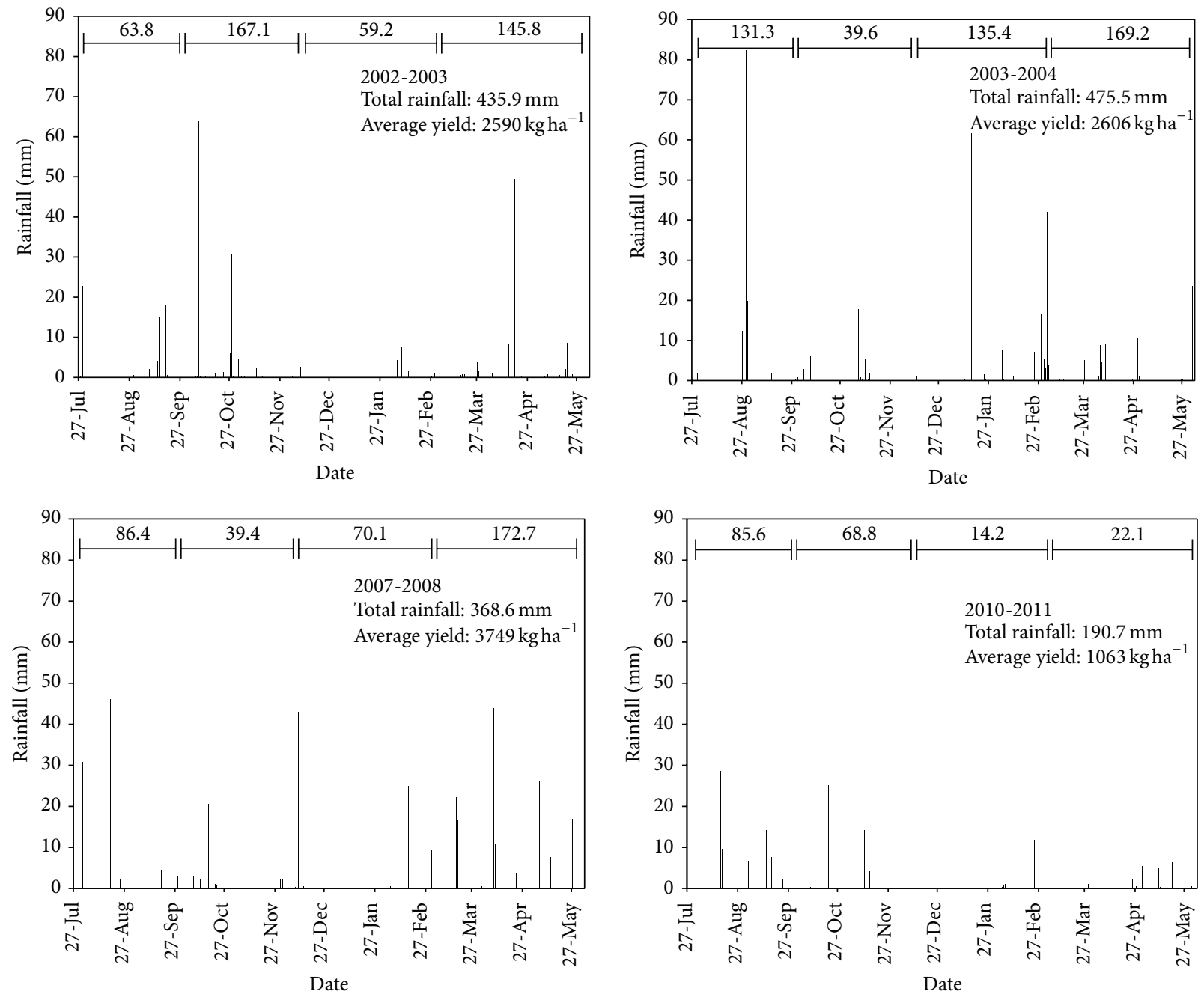

FIGURE 1: Rainfall distribution for Altus, Oklahoma, area from the average time of preplant irrigation to the average time of grain harvest for years analyzed. Data obtained from the Oklahoma Mesonet climate monitoring station [31].

TABLE 4: Grain yield and water use efficiency (WUE) interaction means by year for plots that received either irrigation or were rain-fed and received their total $\mathrm{N}$ fertilizer preplant or topdressed midseason.

\begin{tabular}{lccccc}
\hline & \multicolumn{3}{c}{ Year } & \multicolumn{2}{c}{ Year } \\
& $\begin{array}{c}2003 \\
\text { Grain yield }\left(\mathrm{kg} \mathrm{ha}^{-1}\right)\end{array}$ & $\begin{array}{c}2003 \\
\text { WUE }\left(\mathrm{kg} \mathrm{ha}^{-1} \mathrm{~mm}^{-1}\right)\end{array}$ \\
\hline Irrigated & & & & & \\
Preplant & 2730 & 4213 & 1397 & 5.1 & 9.0 \\
Topdress & 2596 & 3757 & 1106 & 4.8 & 8.0 \\
Rain-fed & & & & & \\
Preplant & 2438 & 3355 & 849 & 5.6 & 9.1 \\
Topdress & 2598 & 3640 & 900 & 6.0 & 9.9 \\
\hline SED & 56 & 161 & 65 & 0.1 & 0.4
\end{tabular}

${ }^{\mathrm{a}}$ Standard error of the difference for the interaction of water and $\mathrm{N}$ application timing.

however, treatments in 2003 that received $45 \mathrm{~kg} \mathrm{Nha}^{-1}$ topdress were significantly higher than those that received the same amount of $\mathrm{N}$ prior to planting. Treatments that received $90 \mathrm{~kg} \mathrm{Nha}^{-1}$ preplant had significant increases in grain yield by $247 \mathrm{~kg} \mathrm{ha}^{-1}$ and $338 \mathrm{~kg} \mathrm{ha}^{-1}$ for 2003 and 2008, respectively, but no significant difference was detected for 2011. The addition of $\mathrm{P}$ and $\mathrm{K}$ was not affected by $\mathrm{N}$ fertilizer timing in 2003 and 2011, but significant grain yield increases were observed for plots that received both $\mathrm{P}$ and $\mathrm{K}$ fertilizer and received $\mathrm{N}$ prior to planting instead of topdress in the spring in 2008. When investigating the response to $\mathrm{P}$ and $\mathrm{K}$ fertilization for $\mathrm{N}$ fertilizer application times separately, yield increases were observed for each $\mathrm{N}$ application time and addition of P fertilizer for both 2003 and 2008. However, significant yield decreases were observed for both $\mathrm{N}$ application times with the addition of P in 2011. The addition of $\mathrm{K}$ fertilizer paired with preplant $\mathrm{N}$ application significantly decreased yields for both 2003 and 2011 and did not have any effect on yield in 2008. No significant differences in $\mathrm{K}$ fertilizer responses were observed when $\mathrm{N}$ fertilizer was topdress applied in the spring of 2003, 2008, and 2011.

For the interaction effect of irrigation and fertilizer treatment on grain yield, treatments that received irrigation 

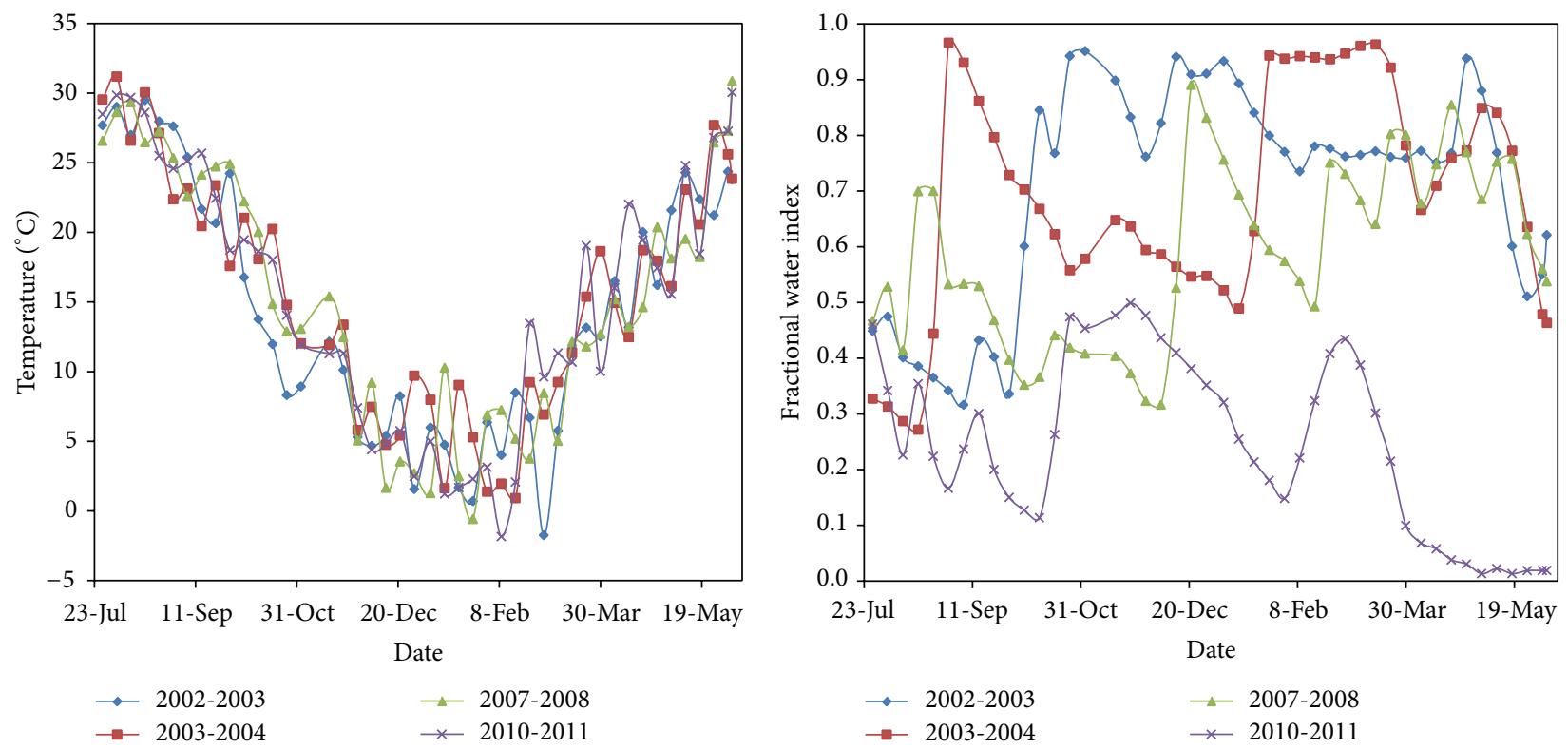

FIGURE 2: Average weekly air temperature and fractional water index for Altus, Oklahoma, from the average time of preplant irrigation to the average time of grain harvest for years analyzed. Data obtained from the Oklahoma Mesonet climate monitoring station [31].

prior to planting had higher grain yields in 2003, 2008, and 2011 (Table 6). Single degree-of-freedom contrasts revealed numerous significant differences (Table 6). Irrigated plots that received both rates of $\mathrm{N}$ and $\mathrm{P}$ fertilizer and $\mathrm{K}$ fertilizer had increased yields compared to the same rain-fed treatments. In 2003 and 2008, regardless of $\mathrm{N}$ application time, the $90 \mathrm{~kg} \mathrm{Nha}^{-1}$ rate of $\mathrm{N}$ fertilizer treatment had higher grain yields than the $45 \mathrm{~kg} \mathrm{~N} \mathrm{ha}^{-1}$ rate. The same trend was observed for the irrigated treatment in 2003 and 2008; however, in the rain-fed treatments no significant differences were observed in grain yields between the two $\mathrm{N}$ fertilizer rates for 2003 and 2008. In 2011, the differences between $\mathrm{N}$ fertilizer rates were significantly higher for the $45 \mathrm{~kg} \mathrm{~N} \mathrm{ha}^{-1}$ rate. This was true regardless of irrigation treatment and when irrigated and/or rain-fed sites were analyzed separately. The addition of $\mathrm{P}$ fertilizer significantly increased yields in irrigated treatments in 2003 and 2008 but significantly decreased yields in 2011. No differences were detected in 2003 and 2008 with the addition of $\mathrm{P}$ fertilizer in rain-fed plots, but, like the irrigated treatments, the addition of $\mathrm{P}$ fertilizer significantly decreased yields in 2011. The addition of $\mathrm{K}$ fertilizer appeared to have little effect on grain yield, regardless whether the plots were irrigated or rain-fed. The only significant difference occurred in 2003 when addition of $\mathrm{K}$ decreased yields in irrigated treatments. When grouping the fertilizer treatments that received $90 \mathrm{~kg} \mathrm{Nha}^{-1}$ and $\mathrm{P}$ fertilizer, the addition of $\mathrm{P}$ fertilizer in irrigated treatments increased yields in 2003 and 2008, but decreased yield in 2011. For the other treatments that received $90 \mathrm{~kg} \mathrm{~N} \mathrm{ha}^{-1}$, there was no difference in $\mathrm{P}$ fertilization under rain-fed conditions and no meaningful differences were observed with the addition of $\mathrm{K}$ fertilizer under irrigated and rain-fed conditions.

In 2004, significant differences among the main effects of fertilizer treatment and $\mathrm{N}$ application time were observed.
Overall, treatments that received $90 \mathrm{~kg} \mathrm{Nha}^{-1}$ compared to $45 \mathrm{~kg} \mathrm{~N} \mathrm{ha}^{-1}$ had higher grain yields (Table 7). Single degreeof-freedom contrasts showed that there was no effect of adding $\mathrm{P}$ or $\mathrm{K}$ fertilizer in 2004 (Table 7). Grain yields of treatments receiving preplant $\mathrm{N}$ fertilizer applications were significantly higher than topdress $\mathrm{N}$ fertilized treatments, but only by $139 \mathrm{~kg} \mathrm{ha}^{-1}$.

3.2. Effect on Water Use Efficiency. Analysis of variance on WUE found no significant three-way interaction for irrigation, $\mathrm{N}$ application time, and fertilizer treatment for site-years (Table 3). The 2003 and 2011 growing seasons had a significant two-way interaction for irrigation and fertilizer treatment. All four site-years had a significant two-way interaction for $\mathrm{N}$ fertilizer application timing and fertilizer treatment (Table 3). The interaction of irrigation and $\mathrm{N}$ fertilizer application timing was only significant for 2003 and 2008. It should be noted that irrigation had a significant effect for 2003, 2004, and 2008; however, drought conditions were so severe in 2011 that no differences were observed.

In 2003 and 2008, the highest WUE for the interactive effect of irrigation and timing of $\mathrm{N}$ fertilizer application was reported for the rain-fed treatments that received topdress $\mathrm{N}$ in the spring (Table 4). Both $\mathrm{N}$ application timings in the rain-fed treatments had higher WUE values compared to the irrigated treatments in both 2003 and 2008. When analyzing only the irrigated treatments, those that received preplant $\mathrm{N}$ fertilizer had significantly higher WUE values for both years (Table 4). Though the trends among treatments were the same for both years, the magnitudes of WUE were different for each individual year. The treatments in 2008 yielded around 40 percent higher WUE values compared to 2003. 
TABLE 5: Grain yield means and selected contrasts by year for plots with different fertilizer treatments and those received either their total N fertilizer preplant or topdressed midseason.

(a)

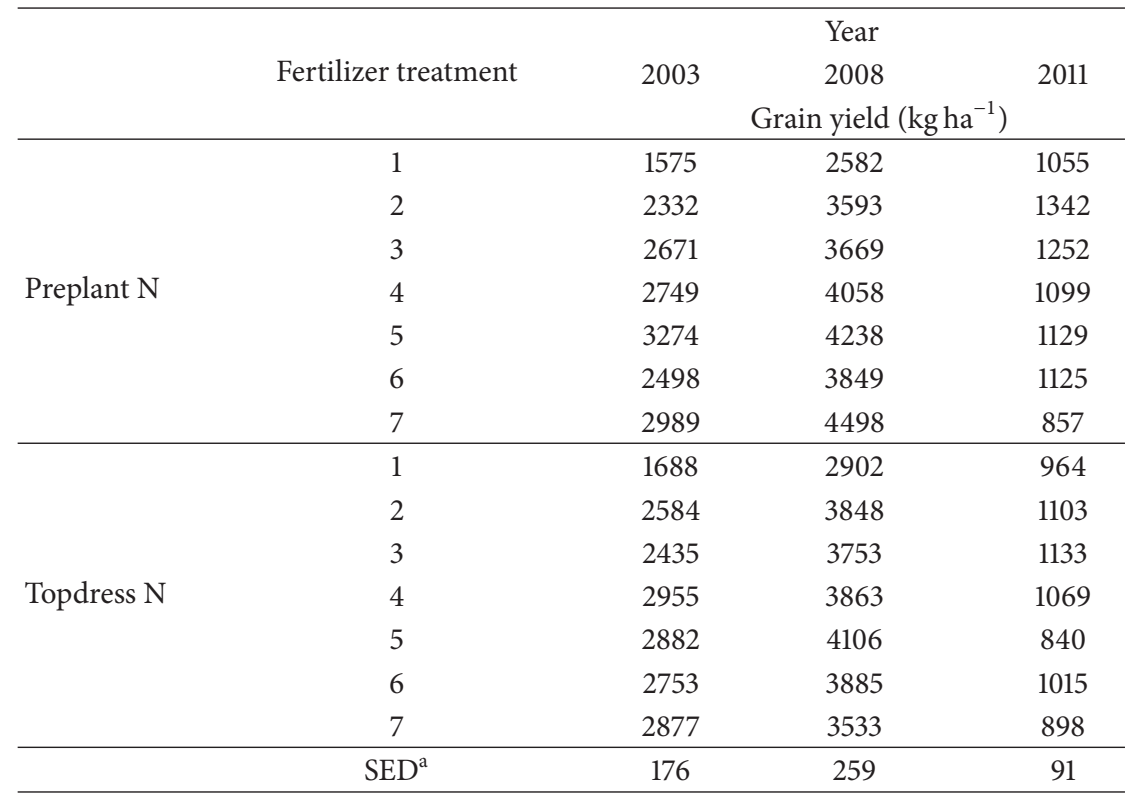

(b)

\begin{tabular}{|c|c|c|c|c|c|c|}
\hline \multirow{3}{*}{ Contrasts } & \multicolumn{6}{|c|}{ Year } \\
\hline & \multicolumn{2}{|c|}{2003} & \multicolumn{2}{|c|}{2008} & \multicolumn{2}{|c|}{2011} \\
\hline & Sig & Dif & Sig & Dif & Sig & Dif \\
\hline $45 \mathrm{~kg} \mathrm{~N} \mathrm{ha}^{-1}$ at preplant versus $45 \mathrm{~kg} \mathrm{~N} \mathrm{ha}^{-1}$ at topdress & $*$ & -238 & $\mathrm{~ns}$ & -32 & ns & 127 \\
\hline $90 \mathrm{~kg} \mathrm{~N} \mathrm{ha}^{-1}$ at preplant versus $90 \mathrm{~kg} \mathrm{~N} \mathrm{ha}^{-1}$ at topdress & * & 247 & * & 338 & ns & 122 \\
\hline $45 \mathrm{~kg} \mathrm{~N} \mathrm{ha}^{-1}$ versus $90 \mathrm{~kg} \mathrm{~N} \mathrm{ha}^{-1}$ & $* *$ & -210 & ns & -117 & $* * *$ & 107 \\
\hline Preplant $45 \mathrm{~kg} \mathrm{~N} \mathrm{ha}^{-1}$ versus $90 \mathrm{~kg} \mathrm{~N} \mathrm{ha}^{-1}$ & $* * *$ & -452 & * & -301 & * & 109 \\
\hline Topdress $45 \mathrm{~kg} \mathrm{~N}$ ha $^{-1}$ versus $90 \mathrm{~kg} \mathrm{~N} \mathrm{ha}^{-1}$ & ns & 33 & ns & 68 & * & 105 \\
\hline $\mathrm{P}$ fertilizer with preplant $\mathrm{N}$ versus with topdress $\mathrm{N}$ & ns & 10 & * & 314 & ns & 97 \\
\hline $\mathrm{K}$ fertilizer with preplant $\mathrm{N}$ versus with topdress $\mathrm{N}$ & ns & -72 & * & 465 & ns & 35 \\
\hline Preplant N-P fertilizer added versus no P fertilizer added & $* * *$ & 510 & $* *$ & 517 & $* *$ & -183 \\
\hline Topdress N-P fertilizer added versus no $\mathrm{P}$ fertilizer added & ** & 409 & ns & 183 & $* *$ & -163 \\
\hline Preplant N-K fertilizer added versus no K fertilizer added & * & -268 & ns & 26 & * & -123 \\
\hline Topdress N-K fertilizer added versus no K fertilizer added & ns & -104 & ns & -275 & ns & 2 \\
\hline
\end{tabular}

${ }^{\mathrm{a}}$ Standard error of the difference for the interaction of $\mathrm{N}$ application timing and fertilizer treatment.

$*, * *$, and $* * *$ are significant at the $0.1,0.01$, and 0.001 level, respectively.

ns: not significant at the 0.1 level.

As previously stated, the two-way interaction of $\mathrm{N}$ fertilizer application time and fertilizer treatment on WUE was significant for all four years. The 2008 growing season had the highest WUE values across all treatments, whereas the 2011 growing season had the lowest WUE values across all treatments. This is likely because 2008 had the highest grain yield for all years evaluated and 2011 had the lowest grain yields for all years evaluated. Fertilizer treatment groupings that were partitioned using single degree-of-freedom contrasts revealed several significant differences (Table 8). The $45 \mathrm{~kg} \mathrm{Nha}^{-1}$ topdress application increased WUE for each year except for 2011. However, the preplant $90 \mathrm{~kg} \mathrm{Nha}^{-1}$ application compared to topdress increased WUE for all four years. The treatments receiving $90 \mathrm{~kg} \mathrm{Nha}^{-1}$ compared to the lower $\mathrm{N}$ rates displayed higher WUE values for 2003, 2004, and 2008, especially those treatments that were irrigated. However, in 2011, the $45 \mathrm{~kg} \mathrm{~N} \mathrm{ha}^{-1}$ treatments had significantly higher WUE values than the higher $\mathrm{N}$ rates for both the irrigated and rain-fed treatments. Treatments that received $\mathrm{P}$ fertilizer and preplant $\mathrm{N}$ fertilizer had increases in WUE for 2004, 2008, and 2011 but decreased WUE in 2003. There were no significant effects of $\mathrm{N}$ application timing on K fertilized plots for 2003, 2004, and 2011, but WUE was significantly higher in 2008 for $\mathrm{K}$ fertilized plots that received $\mathrm{N}$ prior to planting compared to a topdress $\mathrm{N}$ application. For plots that received $\mathrm{N}$ fertilizer prior to planting the addition 
TABLE 6: Grain yield means and selected contrasts by year for plots with different fertilizer treatments and those either received a flush of irrigation prior to planting or did not receive irrigation.

(a)

\begin{tabular}{ccccc}
\hline & & & Year & \\
& Fertilizer treatment & 2003 & $\begin{array}{c}2008 \\
\text { Grain yield }\left(\mathrm{kg} \mathrm{ha}^{-1}\right)\end{array}$ & \\
\hline & 1 & 1452 & 2726 & 1097 \\
& 2 & 2508 & 3900 & 1369 \\
Irrigated & 3 & 2465 & 3887 & 1512 \\
& 4 & 3126 & 4112 & 1344 \\
& 5 & 3393 & 4623 & 1129 \\
& 6 & 2541 & 4158 & 1229 \\
& 7 & 3152 & 4488 & 1079 \\
\hline \multirow{3}{*}{ Rain-fed } & 1 & 1811 & 2757 & 923 \\
& 2 & 2408 & 3541 & 1076 \\
& 3 & 2641 & 3536 & 873 \\
& 4 & 2579 & 3809 & 823 \\
& 5 & 2763 & 3720 & 840 \\
& 6 & 2710 & 3576 & 911 \\
& 7 & 2713 & 3542 & 677 \\
\hline
\end{tabular}

(b)

\begin{tabular}{|c|c|c|c|c|c|c|}
\hline \multirow{3}{*}{ Contrasts } & \multicolumn{6}{|c|}{ Year } \\
\hline & \multicolumn{2}{|c|}{2003} & \multicolumn{2}{|c|}{2008} & \multicolumn{2}{|c|}{2011} \\
\hline & Sig & Dif & Sig & Dif & Sig & Dif \\
\hline $\mathrm{P}$ fertilizer added irrigated versus rain-fed & $* * *$ & 362 & $* * *$ & 684 & $* * *$ & 382 \\
\hline $\mathrm{K}$ fertilizer added irrigated versus rain-fed & ns & 135 & $* * *$ & 764 & $* * *$ & 360 \\
\hline $45 \mathrm{~kg} \mathrm{~N} \mathrm{ha}^{-1}$ irrigated versus $45 \mathrm{~kg} \mathrm{~N} \mathrm{ha}^{-1}$ rain-fed & * & 159 & ** & 415 & $* * *$ & 377 \\
\hline $90 \mathrm{~kg} \mathrm{~N} \mathrm{ha}^{-1}$ irrigated versus $90 \mathrm{~kg} \mathrm{~N} \mathrm{ha}^{-1}$ rain-fed & $* * *$ & 298 & $* * *$ & 734 & $* * *$ & 443 \\
\hline $45 \mathrm{~kg} \mathrm{~N} \mathrm{ha}^{-1}$ versus $90 \mathrm{~kg} \mathrm{~N} \mathrm{ha}^{-1}$ & $* *$ & -210 & ns & -117 & $* * *$ & 107 \\
\hline Irrigated $45 \mathrm{~kg} \mathrm{~N} \mathrm{ha}^{-1}$ versus $90 \mathrm{~kg} \mathrm{~N} \mathrm{ha}^{-1}$ & * & -279 & * & -276 & * & 74 \\
\hline Rain-fed $45 \mathrm{~kg} \mathrm{~N} \mathrm{ha}^{-1}$ versus $90 \mathrm{~kg} \mathrm{~N} \mathrm{ha}^{-1}$ & ns & -140 & ns & 43 & ** & 140 \\
\hline Irrigated $\mathrm{P}$ fertilizer added versus no $\mathrm{P}$ fertilizer added & $* * *$ & 772 & ** & 474 & $* * *$ & -204 \\
\hline Rain-fed $\mathrm{P}$ fertilizer added versus no $\mathrm{P}$ fertilizer added & ns & 146 & ns & 226 & ** & -142 \\
\hline Irrigated $\mathrm{K}$ fertilizer added versus no $\mathrm{K}$ fertilizer added & $* *$ & -413 & ns & -44 & ns & -83 \\
\hline Rain-fed $\mathrm{K}$ fertilizer added versus no $\mathrm{K}$ fertilizer added & ns & 41 & ns & -206 & ns & 39 \\
\hline Irrigated, $90 \mathrm{~kg} \mathrm{~N} \mathrm{ha}^{-1}$, $\mathrm{P}$ fertilizer added versus no $\mathrm{P}$ fertilizer added & $* * *$ & 928 & $* *$ & 736 & $* * *$ & -383 \\
\hline Rain-fed, $90 \mathrm{~kg} \mathrm{~N} \mathrm{ha}^{-1}$, $\mathrm{P}$ fertilizer added versus no $\mathrm{P}$ fertilizer added & ns & 121 & ns & 184 & ns & -33 \\
\hline Irrigated, $90 \mathrm{~kg} \mathrm{~N} \mathrm{ha}^{-1}$, $\mathrm{K}$ fertilizer added versus no $\mathrm{K}$ fertilizer added & ns & -241 & ns & -135 & ns & -50 \\
\hline Rain-fed, $90 \mathrm{~kg} \mathrm{~N} \mathrm{ha}{ }^{-1}, \mathrm{~K}$ fertilizer added versus no $\mathrm{K}$ fertilizer added & ns & -49 & ns & 178 & $*$ & -164 \\
\hline
\end{tabular}

${ }^{a}$ Standard error of the difference for the interaction of fertilizer treatment and water treatment. $*, * *$, and $* * *$ are significant at the $0.1,0.01$, and 0.001 level, respectively. ns: not significant at the 0.1 level.

of P increased WUE in 2003, 2004, and 2008 compared to plots that did not receive any $\mathrm{P}$ fertilizer. The opposite was true in 2011, where the addition of P fertilizer decreased WUE on treatments that received $\mathrm{N}$ prior to planting. Treatments that received topdress $\mathrm{N}$ fertilizer applications in the spring were not significantly affected by the addition of $\mathrm{P}$ fertilizer in 2004 and 2008, but an increase in WUE was observed in 2003 and a decrease in WUE was observed in 2011. The addition of $\mathrm{K}$ fertilizer in treatments that received preplant $\mathrm{N}$ fertilizer applications compared to treatments that did not receive $\mathrm{K}$ fertilizer were not significantly different in 2004 and 2008, but WUE was significantly decreased in 2003 and 2011. No significant decreases or increases in WUE were observed in treatments that received topdress $\mathrm{N}$ applications and did or did not receive $\mathrm{K}$ fertilization.

The only years to have the significant two-way interaction of irrigation and fertilizer treatment were 2003 and 2011. In 2003, irrigated plots displayed lower WUE values than 
TABLE 7: Grain yield means and selected contrasts for the significant main effects of fertilizer treatment and $\mathrm{N}$ application timing for 2004 growing season.

(a)

\begin{tabular}{lccc}
\hline $\begin{array}{l}\text { Fertilizer } \\
\text { treatment }\end{array}$ & $\begin{array}{c}\text { Grain yield } \\
\left(\mathrm{kg} \mathrm{ha}^{-1}\right)\end{array}$ & $\begin{array}{c}\text { N application } \\
\text { time }\end{array}$ & $\begin{array}{c}\text { Grain yield } \\
\left(\mathrm{kg} \mathrm{ha}^{-1}\right)\end{array}$ \\
\hline 1 & 1569 & Preplant & 2676 \\
2 & 2688 & Topdress & 2537 \\
3 & 2852 & SED $^{\mathrm{a}}$ & $\mathbf{6 1}$ \\
4 & 2607 & & \\
5 & 2921 & & \\
6 & 2725 & & \\
7 & 2883 & & \\
SED $^{\mathrm{a}}$ & $\mathbf{1 5 1}$ & & \\
\hline
\end{tabular}

(b)

\begin{tabular}{lcc}
\hline Contrasts & Sig & Dif \\
\hline P fertilizer added versus No P fertilizer added & ns & -6 \\
K fertilizer added versus No K fertilizer added & ns & 40 \\
$45 \mathrm{~kg} \mathrm{~N} \mathrm{ha}^{-1}$ versus $90 \mathrm{~kg} \mathrm{~N} \mathrm{ha}^{-1}$ & $*$ & -212 \\
\hline
\end{tabular}

${ }^{a}$ SED: standard error of the difference between the main effects of fertilizer treatment and $\mathrm{N}$ application timing.

$*$ is significant at the 0.1 level.

ns: not significant at the 0.1 level.

rain-fed plots. In 2011, irrigated treatments had slightly lower WUE values but were not as high as 2003 (Table 9). Several groupings based upon fertilizer treatment and irrigated versus rain-fed moisture conditions exhibited significant differences based upon single degree-of-freedom contrasts (Table 9). Irrigated treatments that received $\mathrm{P}$ or $\mathrm{K}$ fertilizer applications had decreased WUE for both years compared to rain-fed treatments. Treatments that received $45 \mathrm{~kg} \mathrm{~N}^{-1}$ had lower WUE values in irrigated plots compared to rain-fed plots for both 2003 and 2011. The same trend was observed for plots that received $90 \mathrm{~kg} \mathrm{Nha}^{-1}$ in 2003, but there was no significant difference in WUE for irrigated versus rain-fed plots in 2011. For the 2003 growing season, the addition of $\mathrm{P}$ or $\mathrm{K}$ fertilizer compared to plots that did not receive $\mathrm{P}$ or $\mathrm{K}$ fertilizer revealed only two significant differences in WUE values. Irrigated treatments that did not receive $\mathrm{K}$ fertilizer had higher WUE values than treatments that received $K$ fertilizer. Irrigated treatments that received $90 \mathrm{~kg} \mathrm{~N} \mathrm{ha}^{-1}$ and $P$ fertilizer application had increased WUE values compared to treatments that did not receive P fertilizer. In 2011, regardless whether the treatment was irrigated or rain-fed or whether the higher rate of $\mathrm{N}$ was applied, WUE values were always lower in plots that received $\mathrm{P}$ or $\mathrm{K}$ fertilizer.

\section{Discussion}

The increased grain yield for plots that received a flush of irrigation and $\mathrm{N}$ fertilizer prior to planting in 2003, 2008, and 2011 is what was to be expected based upon others findings [3]. The adequate soil moisture at planting allowed for an improved stand establishment coupled with stimulated root and plant growth from the addition of $\mathrm{N}$ fertilizer. The interaction of irrigation and $\mathrm{N}$ fertilizer application timing was found not to be significant in 2004. This is likely because, in $2004,131 \mathrm{~mm}$ of rain was received between late July and early October, the most for any of the four years analyzed (Figure 1). This amount of rainfall possibly negated the effect of preplant irrigation on plant growth. The minimal increase in grain yields in 2003, 2008, and 2011 for rain-fed plots that received topdress $\mathrm{N}$ fertilizer could likely be due to the $\mathrm{N}$ fertilizer being applied to an actively growing crop with an established root system compared to that being applied prior to planting. There have been numerous conflicting results reported as to which is the most appropriate $\mathrm{N}$ application time to maximize grain yields in rain-fed winter wheat. The results, that spring only $\mathrm{N}$ fertilizer applications have the potential to produce higher grain yields, reported in this study do agree with what has been reported by others such as Vaughan et al. [33].

As stated earlier, treatments that received the high $\mathrm{N}$ fertilizer rate prior to planting and $\mathrm{P}$ fertilizer exhibited higher grain yields in 2003 and 2008 (irrigated and/or rainfed). Differences likely were not seen in 2004 because of ample precipitation and in 2011 because of severe drought (Figure 1). The only logical explanation for the significant increase in grain yield for the 2003 fertilizer treatments that received $45 \mathrm{~kg} \mathrm{Nha}^{-1}$ midseason compared to $\mathrm{N}$ applications prior to planting is that the period from planting to the average break of dormancy received the most amount of rainfall of any of the four years analyzed (Figure 1). The soil being near saturation during this period, confirmed by the elevated FWI values over this time (Figure 2), is ideal for $\mathrm{N}$ losses via denitrification [34].

The average soil test $\mathrm{P}$ values since the establishment of this trial for treatments that do not receive $\mathrm{P}$ fertilizer and do receive $\mathrm{P}$ fertilizer were 6 and $21 \mathrm{mg} \mathrm{P} \mathrm{kg}^{-1}$ for the irrigated site and 4 and $27 \mathrm{mg} \mathrm{P} \mathrm{kg}^{-1}$ for the rain-fed site, respectively (Table 1). Based on the soil test $\mathrm{P}$ values and the current Oklahoma State University recommendations [35], the sites that have received $\mathrm{P}$ fertilizer over the 45 plus years of this experiment have maintained soil test $P$ values above sufficient levels. The treatments not receiving any $\mathrm{P}$ fertilizer have been at best 50 percent sufficient; thus it can be concluded when differences in $\mathrm{P}$ fertilizer response were detected, it was likely due more to the treatment being deficient in $\mathrm{P}$ and not so much the addition of $\mathrm{P}$ fertilizer.

A response to $\mathrm{K}$ fertilization on the soil type used in this study is not to be expected. The Hollister soil series has a clay mineralogy class denoted as smectitic [29]. Smectitic or montmorillonitic clays in semiarid regions are known for their shrink-swell properties and typically are high in $\mathrm{K}$ that is easily exchangeable or fixed within the clay lattices $[36,37]$. The average soil test $\mathrm{K}$ values since the establishment of this trial for treatments that do not receive $\mathrm{K}$ fertilizer and do receive $\mathrm{K}$ fertilizer were 302 and $328 \mathrm{mg} \mathrm{K} \mathrm{kg}^{-1}$ for the irrigated site and 334 and $368 \mathrm{mg} \mathrm{Kkg}^{-1}$ for the rainfed site, respectively. Treatments that have not received any $\mathrm{K}$ fertilizer in the 45 plus years of this experiment have soil 
TABLE 8: Water use efficiency (WUE) means and selected contrasts by year for plots with different fertilizer treatments and those received either their total $\mathrm{N}$ fertilizer preplant or topdressed midseason.

(a)

\begin{tabular}{lccccc}
\hline & & \multicolumn{4}{c}{ Year } \\
& Fertilizer treatment & 2003 & $\begin{array}{c}2004 \\
\text { WUE }\left(\mathrm{kg} \mathrm{ha}^{-1} \mathrm{~mm}^{-1}\right)\end{array}$ & \\
\hline \multirow{3}{*}{ Preplant N } & 1 & 3.3 & 3.1 & 6.2 & 4.5 \\
& 2 & 4.8 & 5.0 & 8.6 & 5.7 \\
& 3 & 5.5 & 5.5 & 8.7 & 5.0 \\
& 4 & 5.6 & 4.9 & 9.7 & 4.4 \\
& 5 & 6.7 & 6.2 & 10.1 & 4.7 \\
Topdress N & 6 & 5.2 & 5.2 & 9.2 & 4.6 \\
& 7 & 6.2 & 5.9 & 10.7 & 3.4 \\
\hline & 1 & 3.5 & 2.9 & 7.1 & 4.1 \\
& 2 & 5.4 & 5.3 & 9.3 & 4.7 \\
& 3 & 5.1 & 5.4 & 9.1 & 4.7 \\
& 4 & 6.1 & 5.1 & 9.3 & 4.5 \\
& 5 & 5.9 & 4.9 & 9.9 & 3.6 \\
& 6 & 5.8 & 5.3 & 9.4 & 4.4 \\
& 7 & 5.9 & 5.2 & 8.4 & 3.8 \\
\hline
\end{tabular}

(b)

\begin{tabular}{|c|c|c|c|c|c|c|c|c|}
\hline \multirow{3}{*}{ Contrasts } & \multicolumn{8}{|c|}{ Year } \\
\hline & \multicolumn{2}{|c|}{2003} & \multicolumn{2}{|c|}{2004} & \multicolumn{2}{|c|}{2008} & \multicolumn{2}{|c|}{2011} \\
\hline & Sig & Dif & Sig & Dif & Sig & Dif & Sig & Dif \\
\hline $45 \mathrm{~kg} \mathrm{~N} \mathrm{ha}^{-1}$ at preplant versus $45 \mathrm{~kg} \mathrm{~N} \mathrm{ha}^{-1}$ at topdress & $* *$ & -0.6 & ns & -0.2 & ns & -0.2 & ns & 0.4 \\
\hline $90 \mathrm{~kg} \mathrm{~N} \mathrm{ha}^{-1}$ at preplant versus $90 \mathrm{~kg} \mathrm{~N} \mathrm{ha}^{-1}$ at topdress & * & 0.5 & ** & 0.7 & ns & 0.7 & ns & 0.3 \\
\hline $45 \mathrm{~kg} \mathrm{~N} \mathrm{ha}^{-1}$ versus $90 \mathrm{~kg} \mathrm{~N} \mathrm{ha}^{-1}$ & $* *$ & -0.4 & * & -0.4 & ns & -0.2 & $* * *$ & 0.5 \\
\hline Preplant $45 \mathrm{~kg} \mathrm{~N} \mathrm{ha}^{-1}$ versus $90 \mathrm{~kg} \mathrm{~N} \mathrm{ha}^{-1}$ & $* * *$ & -1.0 & $* * *$ & -0.8 & * & -0.7 & $* *$ & 0.5 \\
\hline Topdress $45 \mathrm{~kg} \mathrm{~N}$ ha $^{-1}$ versus $90 \mathrm{~kg} \mathrm{~N} \mathrm{ha}^{-1}$ & ns & 0.1 & ns & 0.1 & ns & 0.2 & * & 0.5 \\
\hline $\mathrm{P}$ fertilizer with preplant $\mathrm{N}$ versus with topdress $\mathrm{N}$ & ns & -0.1 & * & 0.4 & ns & 0.6 & ns & 0.2 \\
\hline $\mathrm{K}$ fertilizer with preplant $\mathrm{N}$ versus with topdress $\mathrm{N}$ & ns & -0.2 & ns & 0.3 & * & 1.0 & ns & -0.1 \\
\hline Preplant N-P fertilizer added versus no $\mathrm{P}$ fertilizer added & $* * *$ & 1.0 & ns & 0.3 & $* *$ & 1.2 & ** & -0.8 \\
\hline Topdress N-P fertilizer added versus no P fertilizer added & $* *$ & 0.7 & ns & -0.4 & ns & 0.4 & $* *$ & -0.7 \\
\hline Preplant N-K fertilizer added versus no K fertilizer added & * & -0.5 & ns & -0.1 & ns & 0.1 & * & -0.5 \\
\hline Topdress N-K fertilizer added versus no K fertilizer added & ns & -0.2 & ns & 0.2 & ns & -0.7 & ns & 0.1 \\
\hline
\end{tabular}

${ }^{\mathrm{a}}$ Standard error of the difference for the interaction of $\mathrm{N}$ application timing and fertilizer treatment.

$*$ and $* *$ are significant at the 0.1 level and 0.01 level, respectively.

ns: not significant at the 0.1 level.

test values well above the sufficient soil test $\mathrm{K}$ level that is recommended by Oklahoma State University [35]. The significant increase in grain yield in 2008 for the $\mathrm{K}$ fertilized treatments that received preplant $\mathrm{N}$ compared to those that received topdress $\mathrm{N}$ could be related to the drier soil moisture conditions from planting until the break of dormancy. The improved or more distributed root growth from the addition of $\mathrm{N}$ fertilizer could have aided in the uptake of increased $\mathrm{K}$ and other nutrients during which was the driest period from planting to the average break of dormancy for the four years analyzed (Figure 1).

When comparing the individual $\mathrm{N}, \mathrm{P}$, and $\mathrm{K}$ treatments that were either irrigated or rain-fed in 2003, 2008, and
2011, logically the irrigated treatments displayed higher grain yields. The response to $\mathrm{P}$ fertilizer was expressed for the 2003 and 2008 growing seasons and was more pronounced in the irrigated treatments compared to the rain-fed treatments. The only unexplainable trend when comparing the interaction of irrigation and fertilizer treatment was the significant reduction in grain yield in 2003 for irrigated treatments that received $\mathrm{K}$ fertilizer compared to plots not receiving $\mathrm{K}$ fertilizer. The only rational explanation is something besides treatments affected one of the plots and was not documented anywhere.

The 2011 growing season was characterized as the year that received the least rainfall of any of the four years analyzed 
TABLE 9: Water use efficiency (WUE) means and selected contrasts by year for plots with different fertilizer treatments and those either received a flush of irrigation prior to planting or did not receive irrigation.

(a)

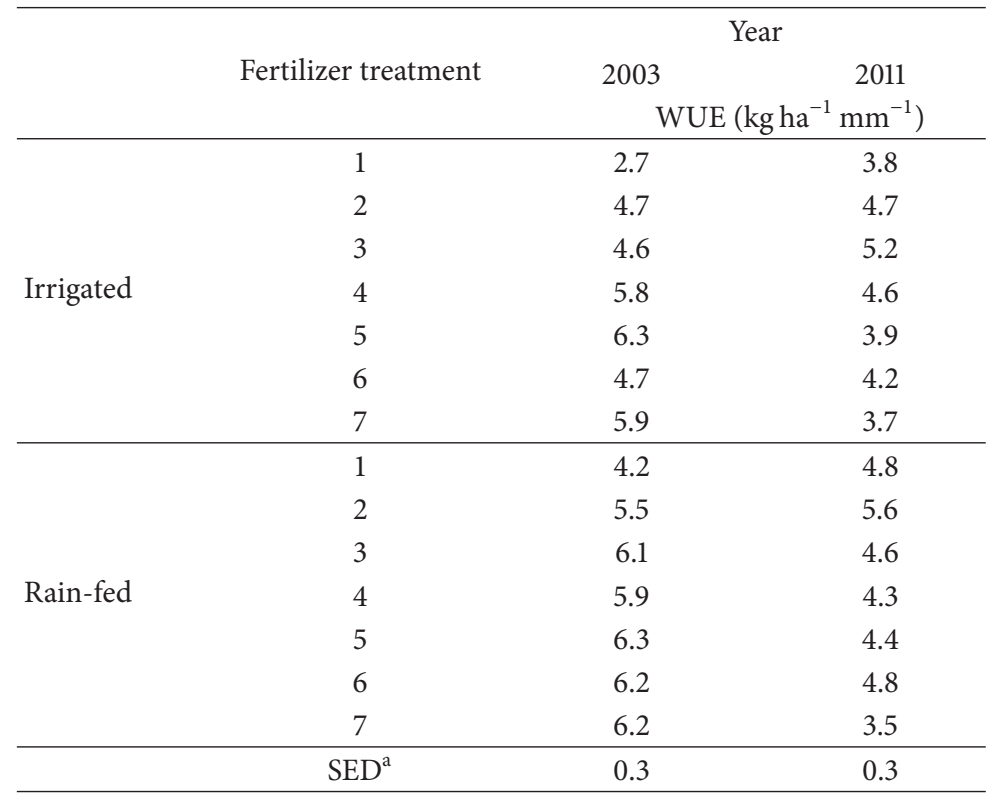

(b)

\begin{tabular}{|c|c|c|c|c|}
\hline \multirow{3}{*}{ Contrasts } & \multicolumn{4}{|c|}{ Year } \\
\hline & \multicolumn{2}{|c|}{2003} & \multicolumn{2}{|c|}{2011} \\
\hline & Sig & Dif & Sig & Dif \\
\hline P fertilizer added irrigated versus rain-fed & $* * *$ & -0.5 & ns & -0.1 \\
\hline $\mathrm{K}$ fertilizer added irrigated versus rain-fed & $* * *$ & -0.9 & ns & -0.2 \\
\hline $45 \mathrm{~kg} \mathrm{~N} \mathrm{ha}^{-1}$ irrigated versus $45 \mathrm{~kg} \mathrm{~N} \mathrm{ha}^{-1}$ rain-fed & $* * *$ & -0.8 & $*$ & -0.4 \\
\hline $90 \mathrm{~kg} \mathrm{~N} \mathrm{ha}^{-1}$ irrigated versus $90 \mathrm{~kg} \mathrm{~N} \mathrm{ha}^{-1}$ rain-fed & $* * *$ & -0.6 & ns & 0.1 \\
\hline $45 \mathrm{~kg} \mathrm{~N} \mathrm{ha}^{-1}$ versus $90 \mathrm{~kg} \mathrm{~N} \mathrm{ha}^{-1}$ & $* *$ & -0.4 & $* * *$ & 0.5 \\
\hline Irrigated $45 \mathrm{~kg} \mathrm{~N} \mathrm{ha}^{-1}$ versus $90 \mathrm{~kg} \mathrm{~N} \mathrm{ha}^{-1}$ & $*$ & -0.5 & ns & 0.3 \\
\hline Rain-fed $45 \mathrm{~kg} \mathrm{~N} \mathrm{ha}{ }^{-1}$ versus $90 \mathrm{~kg} \mathrm{~N} \mathrm{ha}^{-1}$ & ns & -0.3 & $* * *$ & 0.7 \\
\hline Irrigated $\mathrm{P}$ fertilizer added versus no $\mathrm{P}$ fertilizer added & $* * *$ & 1.4 & $* *$ & -0.7 \\
\hline Rain-fed P fertilizer added versus no P fertilizer added & ns & 0.3 & $* *$ & -0.7 \\
\hline Irrigated $\mathrm{K}$ fertilizer added versus no $\mathrm{K}$ fertilizer added & $* *$ & -0.8 & ns & -0.3 \\
\hline Rain-fed $\mathrm{K}$ fertilizer added versus no $\mathrm{K}$ fertilizer added & ns & 0.1 & ns & -0.2 \\
\hline Irrigated, $90 \mathrm{~kg} \mathrm{~N} \mathrm{ha}^{-1}$ and $\mathrm{P}$ fertilizer added versus no $\mathrm{P}$ fertilizer added & $* * *$ & 1.7 & $* * *$ & -1.3 \\
\hline Rain-fed, $90 \mathrm{~kg} \mathrm{~N} \mathrm{ha}^{-1}$ and $\mathrm{P}$ fertilizer added versus no $\mathrm{P}$ fertilizer added & ns & 0.3 & ns & -0.2 \\
\hline Irrigated, $90 \mathrm{~kg} \mathrm{~N} \mathrm{ha}^{-1}$ and $\mathrm{K}$ fertilizer added versus no $\mathrm{K}$ fertilizer added & ns & -0.5 & ns & -0.2 \\
\hline Rain-fed, $90 \mathrm{~kg} \mathrm{~N} \mathrm{ha}^{-1}$ and $\mathrm{K}$ fertilizer added versus no $\mathrm{K}$ fertilizer added & ns & -0.1 & $* *$ & -0.9 \\
\hline
\end{tabular}

${ }^{\mathrm{a}}$ Standard error of the difference for the interaction of fertilizer treatment and water treatment.

$*, * *$, and $* * *$ are significant at the $0.1,0.01$, and 0.001 level, respectively.

ns: not significant at the 0.1 level.

(Figure 1). Trends of decreased yields with the addition of $\mathrm{P}$ and $\mathrm{K}$ fertilizers and the higher rate of $\mathrm{N}$ fertilizer applications were observed for this year. Though these yield decreases were minimal and sometimes not significant, they need to be accounted for. One possible explanation could be that there was a reduced stand and reduced early plant growth caused by salt injury from the fertilizer. Fertilizer injury from N, $\mathrm{P}$, and $\mathrm{K}$ sources are well known and documented and low soil moisture content can greatly increase the potential of fertilizer damage [38-40].

The 2004 growing season was the only year evaluated that did not have any significant differences for the three-way or any of the two-way interactions. This is thought to be because there was more than sufficient rainfall provided throughout the growing season to negate any effect of preplant irrigation (Figure 1). The 2004 crop year had the highest amount of 
total rainfall for any of the crop years evaluated in this study. The distribution of rainfall for the 2004 crop year was fairly evenly distributed with high amounts of precipitation prior to planting to ensure stand establishment and high amounts of rainfall coming around the break of winter dormancy and continuing on through times of rapid growth and nutrient uptake in the spring (Figure 1). This is also exhibited in the trends of the FWI over the growing season (Figure 2). The 2004 crop has the highest FWI at the time of planting, the two weeks prior to, and the two weeks after the topdress $\mathrm{N}$ fertilizer application. The lack of differences between treatments that received $\mathrm{P}$ fertilizer compared to treatments that did not receive $\mathrm{P}$ fertilizer during a year of adequate soil moisture has been reported by other researchers [12-14]. The logic behind this is that adequate water allows for increased root development, which leads to the plant's ability to acquire more of the native soil P. Producers in a rain-fed cropping system will not know at planting, when P fertilizer is applied, whether they will have sufficient moisture throughout the growing season to utilize more native soil P. Nonetheless, it would still be recommended that producers should soil test and apply $\mathrm{P}$ fertilizer to attain sufficient levels.

Because of the methodology used to calculate the WUE for each plot, most of the trends and differences in WUE were similar to the trends and differences observed in grain yield. The methodology used assumes that each plot utilizes the same amount of moisture added. To more accurately measure WUE for each treatment, the soil profile moisture concentration should be collected at both the beginning and the end of the growing season for each plot to know whether the crop utilized more or less soil moisture. One trend that was observed in WUE is that as N fertilizer's rate increased, as long as there is adequate moisture provided, the WUE increased as well and this has been documented by several other researchers $[5,6,41]$. Again, the logic is that with adequate moisture, the addition of $\mathrm{N}$ fertilizer stimulates root growth, which can easily promote the acquisition of more soil water and/or soil nutrients.

\section{Conclusions}

Based upon the findings, whether irrigation or adequate soil moisture conditions are available prior to planting, applying sufficient $\mathrm{N}$ fertilizer preplant is most beneficial to grain yield and WUE in the Central Rolling Red Plains. When the only source of moisture is through the naturally occurring rainfall and soil moisture conditions are average or below average, application timing of $\mathrm{N}$ fertilizer is not as important and can either be applied prior to planting or topdressed in the spring or potentially split between the two. The application of $\mathrm{P}$ fertilizer can be beneficial and producers should soil test and apply P fertilizer to achieve sufficient soil test levels to assist in optimizing grain yields. The application of $\mathrm{K}$ fertilizer is likely not beneficial in this region on these soil types and possibly even aided in the reduction of grain yields during dry years due to salt injury. In conclusion, having knowledge of the soil moisture content at certain times of the growing season, producers can better manage their fertilizer practices in the Central Rolling Red Plains.

\section{Abbreviations}

WUE: Water use efficiency

FWI: Fractional water index.

\section{Conflict of Interests}

The authors declare that there is no conflict of interests regarding the publication of this paper.

\section{Acknowledgments}

The authors would like to thank the Oklahoma Soil Fertility Research and Education Advisory Board for their continued financial support of soil fertility research at Oklahoma State University. The authors would also like to thank the present and past field crew at the Oklahoma State University Southwest Research and Extension Center located near Altus, Oklahoma, for their maintenance of trials and documentation of agronomic activities.

\section{References}

[1] U.S. Department of Agriculture, "Land Resource Regions and Major Land Areas of the United States, the Caribbean, and the Pacific Basin," USDA-NRCS, 2006, http://soils.usda .gov/survey/geography/mlra/index.html.

[2] U.S. Department of Agriculture, Quick Stats. USDA-NASS, 2013, http://www.nass.usda.gov/Quick_Stats/index.php.

[3] J. T. Musick and F. R. Lamm, "Preplant irrigation in the central and southern high plains - a review," Transactions of the American Society of Agricultural Engineers, vol. 33, no. 6, pp. $1834-1842,1990$.

[4] P. R. Gajri, S. S. Prihar, and V. K. Arora, "Effects of nitrogen and early irrigation on root development and water use by wheat on two soils," Field Crops Research, vol. 21, no. 2, pp. 103-114, 1989.

[5] P. R. Gajri, S. S. Prihar, and V. K. Arora, "Interdependence of nitrogen and irrigation effects on growth and input-use efficiencies in wheat," Field Crops Research, vol. 31, no. 1-2, pp. 71-86, 1993.

[6] G. Hussain and A. A. Al-Jaloud, "Effect of irrigation and nitrogen on water use efficiency of wheat in Saudi Arabia," Agricultural Water Management, vol. 27, no. 2, pp. 143-153, 1995.

[7] K. P. Singh and V. Kumar, "Water use and water-use efficiency of wheat and barley in relation to seeding dates, levels of irrigation and nitrogen fertilization," Agricultural Water Management, vol. 3, no. 4, pp. 305-316, 1981.

[8] R. K. Belford, B. Klepper, and R. W. Rickman, "Studies of intact root-shoot systems of field grown winter wheat-II. Root and shoot developmental patterns as related to nitrogen fertilizer," Agronomy Journal, vol. 79, pp. 310-319, 1987.

[9] R. Singh, Y. Singh, S. S. Prihar, and P. Singh, "Effect of N fertilization on yield and water use efficiency of dryland winter wheat as affected by stored water and rainfall," Agronomy Journal, vol. 67, pp. 599-603, 1975.

[10] D. Tennant, "Root growth of wheat-I. Early patterns of multiplication and extension of wheat roots including effects of levels of nitrogen, phosphorus, and potassium," Australian Journal of Agricultural Research, vol. 27, pp. 183-196, 1976. 
[11] S. R. Olsen, F. S. Watanabe, and R. E. Danielson, "Phosphorus absorption by corn roots as affected by moisture and phosphorus concentration," Proceedings of the Soil Science Society of America, vol. 25, pp. 289-294, 1961.

[12] W. M. Strong and G. Barry, "The availability of soil and fertilizer phosphorus to wheat and rape at different water regimes," Australian Journal of Soil Research, vol. 18, pp. 353-362, 1980.

[13] G. A. Reichman and D. L. Grunes, "Effect of water regime and fertilization on barley growth, water use, and N and P uptake," Agronomy Journal, vol. 58, pp. 513-517, 1966.

[14] K. Simpson, "The significance of the effects of soil moisture and temperature on phosphorus uptake," in Soil Phosphorus, Tech. Bull. No. 13, pp. 19-29, Ministry of Agriculture, Fish. Food. H.M.S.O, London, UK, 1965.

[15] R. Kuchenbuch, N. Claassen, and A. Jungk, "Potassium availability in relation to soil moisture," Plant and Soil, vol. 95, no. 2, pp. 233-243, 1986.

[16] S. Seiffert, J. Kaselowsky, A. Jungk, and N. Claassen, “Observed and calculated potassium uptake by maize as affected by soil water content and bulk density," Agronomy Journal, vol. 87, no. 6, pp. 1070-1077, 1995.

[17] Q. Zeng and P. H. Brown, "Soil potassium mobility and uptake by corn under differential soil moisture regimes," Plant and Soil, vol. 221, no. 2, pp. 121-134, 2000.

[18] K. Mengel and L. C. Von Braunschweig, "The effect of soil moisture upon availability of potassium and its influence on the growth of young maize plants (Zea mays L.)," Soil Science, vol. 114, pp. 142-148, 1972.

[19] J. M. Clarke, C. A. Campbell, H. W. Cutforth, R. M. DePauw, and G. E. Winkleman, "Nitrogen and phosphorus uptake, translocation, and utilization efficiency of wheat in relation to environment and cultivar yield and protein levels," Canadian Journal of Plant Science, vol. 70, pp. 965-977, 1990.

[20] T. K. Das and N. T. Yaduraju, "Effect of weed competition on growth, nutrient uptake and yield of wheat as affected by irrigation and fertilizers," Journal of Agricultural Science, vol. 133, no. 1, pp. 45-51, 1999.

[21] H. V. Eck, "Winter wheat response to nitrogen and irrigation," Agronomy Journal, vol. 80, pp. 902-908, 1988.

[22] K. Girma, S. Holtz, B. Tubaña, J. Solie, and W. Raun, "Nitrogen accumulation in shoots as a function of growth stage of corn and winter wheat," Journal of Plant Nutrition, vol. 34, no. 2, pp. 165-182, 2011.

[23] R. K. Boman, R. L. Westerman, W. R. Raun, and M. E. Jojola, "Time of nitrogen application: effects on winter wheat and residual soil nitrate," Soil Science Society of America Journal, vol. 59, no. 5, pp. 1364-1369, 1995.

[24] M. M. Alcoz, F. M. Hons, and V. A. Haby, "Nitrogen fertilization timing effect on wheat production, nitrogen uptake efficiency, and residual soil nitrogen," Agronomy Journal, vol. 85, no. 6, pp. 1198-1203, 1993.

[25] L. F. Welch, P. E. Johnson, J. W. Pendleton, and L. B. Miller, "Efficiency of fall- versus spring-applied nitrogen for winter wheat," Agronomy Journal, vol. 58, pp. 271-274, 1966.

[26] L. A. Harper, R. R. Sharpe, G. W. Langdale, and J. E. Giddens, "Nitrogen cycling in a wheat crop: soil, plant, and aerial nitrogen transport," Agronomy Journal, vol. 79, pp. 965-973, 1987.

[27] R. V. Olson and C. W. Shallow, "Fate of labeled nitrogen fertilizer applied to winter wheat," Soil Science Society of America Journal, vol. 48 , no. 3, pp. 583-586, 1984.
[28] Soil Survey Staff, "Web Soil Survey: Soil Data Mart. USDANRCS," 2013, http://websoilsurvey.nrcs.usda.gov.

[29] Soil Survey Staff, "Official Soil Series Description. USDANRCS," 2002, http://soils.usda.gov/technicalclassification/ osd/index.html.

[30] A. Mehlich, "Mehlich 3 soil test extractant: a modification of Mehlich 2 extractant," Communications in Soil Science \& Plant Analysis, vol. 15, no. 12, pp. 1409-1416, 1984.

[31] Mesonet, Daily Data Retrieval. University of Oklahoma, 2013, http://www.mesonet.org/index.php/weather/category/past_ data_files.

[32] B. G. Illston, J. B. Basara, D. K. Fisher et al., "Mesoscale monitoring of soil moisture across a statewide network," Journal of Atmospheric and Oceanic Technology, vol. 25, no. 2, pp. 167182, 2008.

[33] B. Vaughan, D. G. Westfall, and K. A. Barbarick, "Nitrogen rate and timing effects on winter wheat grain yield, grain protein, and economics," Journal of Production Agriculture, vol. 3, pp. 324-328, 1990.

[34] J. R. Burford and J. M. Bremner, "Relationships between the denitrification capacities of soils and total, water-soluble and readily decomposable soil organic matter," Soil Biology and Biochemistry, vol. 7, no. 6, pp. 389-394, 1975.

[35] H. Zhang and W. R. Raun, Oklahoma Soil Fertility Handbook, Oklahoma State University Press, Stillwater, 6th edition, 2006.

[36] J. L. Havlin, D. G. Westfall, and S. R. Olsen, "Mathematical models for potassium release kinetics in calcareous soils," Soil Science Society of America Journal, vol. 49, no. 2, pp. 371-376, 1985.

[37] G. Sposito, The Chemistry of Soils, Oxford University Press, New York, NY, USA, 2nd edition, 2008.

[38] O. G. Carter, "The effect of chemical fertilizer on seedling establishment," Australian Journal of Experimental Agriculture, vol. 7, pp. 174-180, 1967.

[39] J. M. Scott, R. S. Jessop, R. J. Steer, and G. D. McLachlan, "Effect of nutrient seed coating on the emergence of wheat and oats," Fertilizer Research, vol. 14, no. 3, pp. 205-217, 1987.

[40] C. K. Stevenson and T. E. Bates, "Effect of nitrogen to phosphorus atom ratio of ammonium phosphates on emergence of wheat (Triticum vulgare)," Agronomy Journal, vol. 60, pp. 493495, 1968.

[41] R. E. Ramig and H. F. Rhoades, "Interrelationships of soil moisture level at planting time and nitrogen fertilization on winter wheat production," Agronomy Journal, vol. 55, pp. 123127, 1963. 


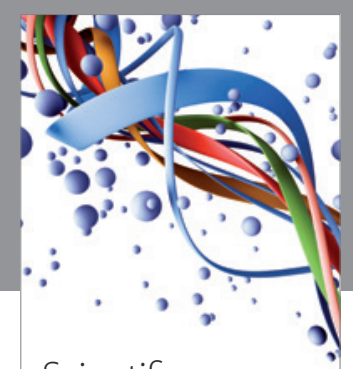

Scientifica
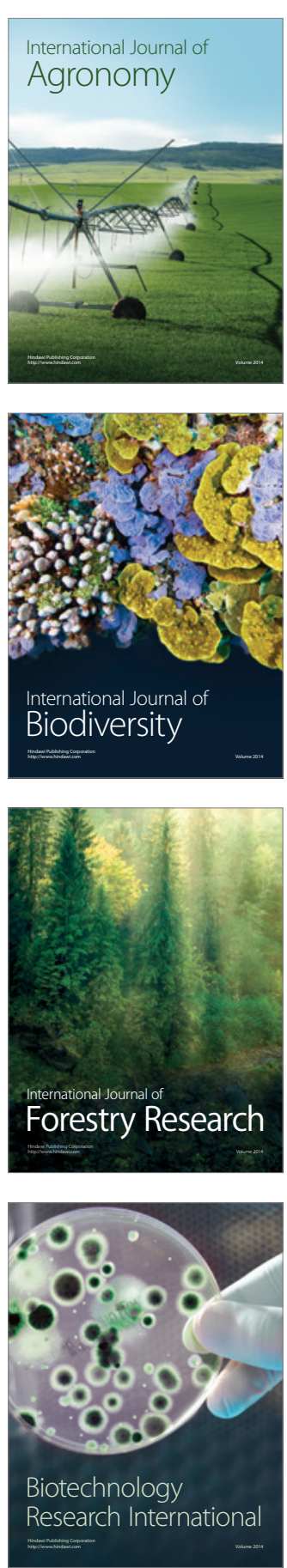
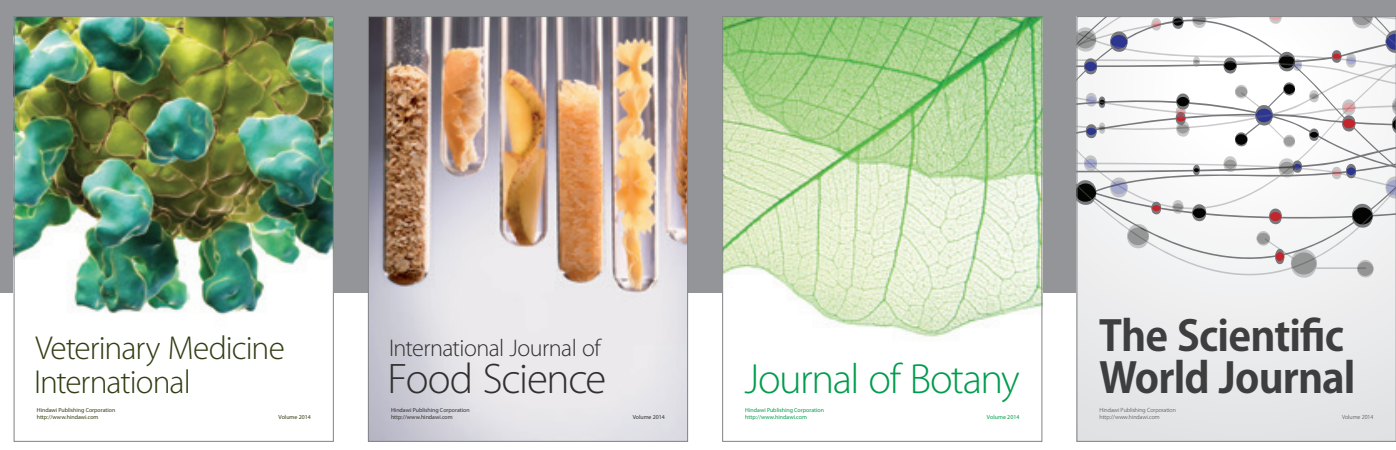

The Scientific World Journal
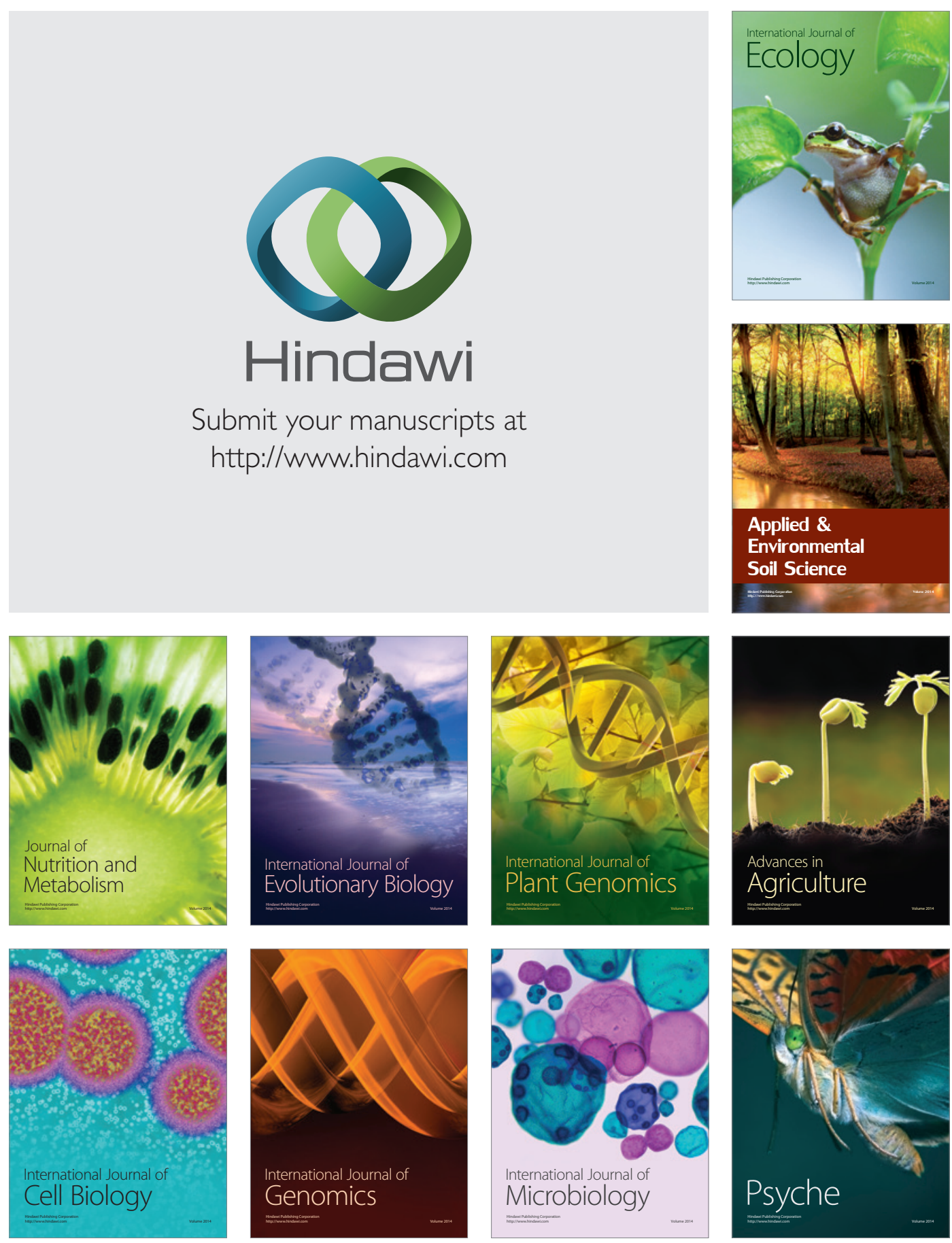